\title{
Genetic Variability of Some Promising Sugarcane Varieties (Saccharum spp) under Harvesting Ages for Juice Quality Traits, Cane and Sugar Yield
}

\author{
Eid M Mehareb ${ }^{1 *}$ and Abazied SR ${ }^{2}$ \\ ${ }^{1}$ Breeding \& Genetic Dept, Sugar Crops Research Inst, Egypt \\ ${ }^{2}$ Sugar Technology Dept, Sugar Crops Research Inst, Egypt
}

\section{Research Article \\ Volume 2 Issue 2}

Received Date: January 26, 2017

Published Date: February 18, 2017

*Corresponding author: Eid M Mehareb, Breeding \& Genetic Department, Sugar Crops

Research Institution, Egypt, E-mail: elmoharb@yahoo.com

\section{Abstract}

The objective of study to estimate genetic variability of some traits in the Egyptian sugarcane breeding program under different harvesting ages (10, 11, 12 and 13 months. Four promising sugarcane verities (C57-14, C203-8, G2003-47 and G99-160) and check cultivar (GT54-9) were evaluated for yield and juice quality traits and genetic parameters were measured in plant cane and first ratoon under Upper Egypt conditions at Kom Ombo Agricultural Research Station, (latitude of $24.28^{\circ} \mathrm{N}$ and longitude of $32.57^{\circ} \mathrm{E}$ ), Aswan Governorate, Egypt during 2014/2015 and 2015/ 2016 seasons. The experimental design was a split plot with three replications. Harvesting ages were arranged in the main plots, whereas; the sub-plots were devoted to the promising sugarcane varieties. The results indicated that harvest age at 13 months recorded the highest mean values of most studied traits, but harvesting age at 13 months not significantly increased cane and sugar yield compared with harvesting at 12 months. The promising sugarcane variety G2003-47 recorded the highest value of all traits compared with other varieties and the commercial variety GT 54-9 in both seasons. Results showed that high genetic variance $\left(\sigma^{2} \mathrm{~g}\right)$ relative to environmental variance for all traits under study across seasons. Moderate values of genotypic coefficient of variation (GCV) and phenotypic coefficient of variation (PCV) were coupled with high heritability for brix, sucrose, richness, sugar recovery and sugar yield. The Highest values of PCV and GCV \% across seasons were observed for reducing sugar (54.310\% and 47.221\%) followed by sugar yield (19.846\% and 19.238\%), respectively. Heritability estimates across seasons exceeded $80 \%$ for all studied traits, except for purity (75.728\%) and reducing sugar (75.596\%). Finally, this study recommends harvesting age 12 or 13 months because there was no significant increase in cane and sugar yield (ton/fad).

Keywords: Sugar cane; Saccharum spp; Harvest Age; Genetic Variance; Heritability; GCV; PCV

\section{Introduction}

The greatest sugar yields for a crop are achieved with mid-season harvesting; however, not all crops can be harvested at this time. Variety-by-time-of-harvest has a lesser effect on cane yield in plant cane 


\section{Open Access Journal of Agricultural Research}

than in ratoon cane, because the plant crop is usually older than 12 months [1]. Harvest times have a significant effect on cane yield in the following crop [1-3]. A longer harvesting season may allow industry to manage increasing production or to support investment opportunities in value-added by-products. The date when sugarcane is harvested affects yield by imposing both crop age and seasonal factors on the crop during its growing season [4-7]. Harvesting time is one of the most important factors affects productivity, and varietal differences in growth and maturity rates [8], so Sundara and Verma $[9,10]$ classified varieties to early, mid and late maturing based on the time taken for maturity.

Evaluation for early maturity, targeting high sucrose content at early age in sugarcane (Saccharum spp L.) is a major objective in breeding programs as demanded by sugar industries [11,12]. It is important that plantbreeding programs select varieties that perform well within a harvest time schedule to maximize potential genetic gains [13]. Optimum sugar yield was recorded on 12 months harvest age with economically acceptable marginal rates of return $178.13 \%$. Therefore, adjusting harvest age to 12 months for the major sugarcane varieties was economically recommended to obtain optimum sugar yield with efficient time use at the tropical areas of Tendaho [14]. Trend analysis of brix-ratio indicated the possibility of harvesting cane earlier [15].

Chaudhary [16] revealed that the stalk weight and millable cane were high genotypic coefficient of variation GCV. Also [17] showed that high GCV, broad sense heritability and expected genetic advance were recorded for stalk diameter, single cane weight and millable cane number. A selection strategy based on these traits could lead to improvement in cane and sugar yield. The present study had the objective of estimating genetic variance and broad sense heritability of sugarcane under different harvesting dates.

\section{Materials and Methods}

The study was carried out at Kom Ombo. Agricultural Research Station, Aswan Governorate (latitude of $24^{\circ} 28^{\prime \prime} \mathrm{N}$ and longitude of $32^{\circ} 57^{\prime \prime} \mathrm{E}$ ), Sugar Crops Research Institute, Agricultural Research Center (ARC), Egypt including plant cane and the $1^{\text {stratoon }}$ crops grown during $2014 / 2015$ and 2015/2016 seasons to evaluate four promising varieties of sugarcane (Saccharum spp L.) C 5714, C 203-8, G.2003-47 and G.99-160 with the check cultivar G.T 54-9 (Table1) for harvesting dates.

\begin{tabular}{|c|c|c|c|}
\hline \multirow{2}{*}{ No. } & \multirow{2}{*}{ Variety name } & \multicolumn{2}{|c|}{ Parents } \\
\cline { 3 - 4 } & & Female & Male \\
\hline 1 & C $57-14$ & C88-553 & Poly cross \\
\hline 2 & C 8-203 & C86-12 & Poly cross \\
\hline 3 & GT.54-9 & NC0.310 & F.37-925 \\
\hline 4 & G.2003-47 & CP.55-30 & $85-1697$ \\
\hline 5 & G.99-160 & Cp.76-1306 & Q.76-1053 \\
\hline
\end{tabular}

Table 1: Pedigree of promising varieties of sugarcane used in the experiment.

A split plot design in three replicates was used where harvesting age were allocated in the main plots while sugarcane varieties were randomly distributed in the sub plots. Sub plot area was $35 \mathrm{~m}^{2}$ including 5 ridges, $7 \mathrm{~m}$ long and $1 \mathrm{~m}$ width. Plant cane was planted in the first week of March using two rows of three-budded cane cuttings. The field was irrigated right after planting and all other agronomic practices were carried out as recommended. Plant cane was allowed to ratoon. Harvest took place 10, 11,12 and 13 months after planting or harvesting date. The field was irrigated right after planting and all other agronomic practices were carried out as recommended. The following traits were measured for promising sugarcane varieties.

\section{A - Juice Quality Traits, Cane and Sugar Yield}

At each harvesting date, twenty five stalks of cane were collected at random to determine the following traits:

1- Brix (percent total soluble solids) was determined using Brix Hydrometer according to AOAC (1995) [18].

2- Sucrose percentage of clarified juice was determined by using automated sacharimeter according to AOAC (1995) [18].

3- Purity percentage: It was calculated according to the following formula of Singh and Singh (1998) [19].

$$
\text { Juice purity percentage }=\frac{\text { sucrosepercentage }}{\text { brix percentage }} \times 100
$$

4- Reducing sugars percentage: It was determined using Fehling method according to AOAC [18].

5- Fiber percentage: at harvest, samples of three stalks were taken, cut and then oven-drying at $105 \mathrm{c}$ to determine fiber \% according to Plskhow [20].

Richness percentage was calculated according to the following formula described by Anonymous.

6 - Richness $\%=$ (sucrose $\%$ gm juice $\mathrm{x}$ richness factor $)$ /100. Where:
Eid M Mehareb and Abazied SR. Genetic Variability of Some Promising Sugarcane Varieties (Saccharum Spp) Under Harvesting Ages for Juice Quality Traits, Cane and Sugar Yield. J Agri Res 2017, 2(2): 000127.
Copyright@ $\subset$ Eid M Mehareb and Abazied SR. 


\section{Open Access Journal of Agricultural Research}

Sucrose $\%$ gm juice $=\left(\right.$ sucrose $\% \mathrm{~cm}^{3}$ juice $) /$ juice density

Juice density was taken from Schibler Tables.

Richness factor $=100$ - (fiber $\%$ x 1.3).

7 - Sugar recovery \% (SR) was calculated according to the formula described by Yadav and Sharma [21].

$\mathrm{SR}=[$ Sucrose \% - 0.4 (Brix - Sucrose \%)] $\mathrm{x} 0.73$

8- Cane yield (ton/fad.) was determined from the weight of the three middle guarded rows of each plot converted into ton per fad.

9- Sugar yield (tons/fad.): was calculated according to the following equation as described by Mathur [22].

Sugar yield (tons/fad.): was calculated according to the following formula described by Mathur [22].

Sugar yield (ton $/$ fad.) $=$ cane yield $($ ton $/$ fad $) \times$ sugar recovery \%.

Data collected were subjected to the proper statistical analysis of variance of split plot design according to the procedures outlined by Snedecor and Chochran [23] to compare between treatment means; L.S.D. at $5 \%$ level of significance was used according to Steel and Torrie [24].

A combined analysis of varieties of the two seasons was done according to Leclerg et al. [25]. All statistical analysis was performed by using analysis of variance technique of (MSTAT) Computer software package.
Where:

$\delta^{2} \mathrm{~g}$ and $\delta^{2} \mathrm{e}$ refers to genotypic and error variance, respectively. The divisor $r$ refers to number of replications, $\delta^{2}$ gy refers to genotype by year interaction variance. The divisor y refers to number of years. $\delta^{2} \mathrm{gh}$ refers to genotype by harvesting date interaction variance and the divisor $\mathrm{h}$ refers to number of harvesting dates. Genetic coefficient of variation (GCV) provides a unit less measure of a trait's genetic variance relative to its mean and calculating as the following equation: $\mathrm{GCV} \%=(\delta \mathrm{g}$ $/$ general mean $) \times 100, \mathrm{PCV} \%=\left(\delta_{\mathrm{ph}} /\right.$ general mean $) \times 100$.

\section{Results and Discussion}

Combined analysis of variance (Table 2) of studied traits revealed highly significant differences among harvesting age for all measured characters. Also the interaction between years and harvesting age was highly significant $(\mathrm{p} \leq 0.01)$ for all studied traits, except for cane yield. Furthermore, mean squares due to varieties were highly significant for all studied traits. Mean squares due to varieties $\times$ year interaction was highly significant for all studied characters, and those for interaction years $\mathrm{x}$ harvesting age $x$ varieties were significant $(p \leq 0.05)$ for fiber, whilst, were highly significant for most studied characters, except for brix and cane yield, which were not significant.

Heritability estimate using variance components from the full model analysis were calculated as: $\mathrm{H}=\delta^{2} \mathrm{~g} /\left(\delta^{2} \mathrm{~g}+\right.$ $\delta^{2}$ gh $/ \mathrm{h}+\delta^{2}$ gy $/ y+\delta^{2}$ ghy $/$ hy $+\delta^{2}{ }_{e} /$ rhy)

\begin{tabular}{|c|c|c|c|c|c|c|}
\hline \multirow{2}{*}{ SOV } & \multirow{2}{*}{ df } & \multicolumn{5}{|c|}{ Mean Squares } \\
\hline & & Brix & Sucrose & Purity & Reducing sugar & Fiber \\
\hline Year & 1 & $5.20^{* *}$ & $3.78^{* *}$ & 1.22 & $1.16^{* *}$ & $2.24^{* *}$ \\
\hline Harvesting age $(\mathrm{H})$ & 3 & $82.06^{* *}$ & $96.65^{* *}$ & $167.44^{* *}$ & $2.83^{* *}$ & $8.95^{* *}$ \\
\hline $\mathrm{Y} \times \mathrm{H}$ & 3 & $4.23^{* *}$ & $6.07 * *$ & $20.04^{* *}$ & $0.30^{* *}$ & $1.06^{* *}$ \\
\hline Error & 12 & 0.17 & 0.14 & 0.54 & 0.02 & 0.26 \\
\hline Varieties (V) & 4 & $19.78^{* *}$ & $21.89 * *$ & $58.20^{* *}$ & $1.21^{* *}$ & $1.35^{* *}$ \\
\hline $\mathrm{YxV}$ & 4 & $3.48^{* *}$ & $6.71^{* *}$ & $39.19 * *$ & $0.61^{* *}$ & $1.85^{* *}$ \\
\hline $\mathrm{HxV}$ & 12 & $1.24^{* *}$ & $2.24^{* *}$ & $17.80^{* *}$ & $0.25^{* *}$ & $0.34^{* *}$ \\
\hline YHV & 12 & 0.54 & $0.74^{* *}$ & $3.23^{* *}$ & $0.15^{* *}$ & $0.28^{*}$ \\
\hline Error & 64 & 0.36 & 0.33 & 0.84 & 0.02 & 0.15 \\
\hline \multirow{2}{*}{ SOV } & \multirow{2}{*}{ df } & \multicolumn{5}{|c|}{ Mean Squares } \\
\hline & & Richness & \multicolumn{2}{|c|}{ Sugar recovery } & Cane yield & Sugar yield \\
\hline Year & 1 & $2.16^{* *}$ & \multicolumn{2}{|c|}{$1.74^{* *}$} & $87.04 * *$ & $2.39 * *$ \\
\hline Harvesting date $(\mathrm{H})$ & 3 & $61.87^{* *}$ & \multicolumn{2}{|c|}{$54.94^{* *}$} & $298.03^{* *}$ & $35.21^{* *}$ \\
\hline $\mathrm{Y} \times \mathrm{H}$ & 3 & $3.85^{* *}$ & \multicolumn{2}{|c|}{$3.70^{* *}$} & 16.36 & $1.39^{* *}$ \\
\hline
\end{tabular}

Eid M Mehareb and Abazied SR. Genetic Variability of Some Promising Copyright@ $\subset$ Eid M Mehareb and Abazied SR. Sugarcane Varieties (Saccharum Spp) Under Harvesting Ages for Juice Quality Traits, Cane and Sugar Yield. J Agri Res 2017, 2(2): 000127. 


\section{Open Access Journal of Agricultural Research}

\begin{tabular}{|c|c|c|c|c|c|}
\hline Error & 12 & 0.11 & 0.07 & 5.78 & 0.16 \\
\hline Varieties $(\mathrm{V})$ & 4 & $14.46^{* *}$ & $12.54^{* *}$ & $885.69^{* *}$ & $17.98^{* *}$ \\
\hline Y x V & 4 & $4.12^{* *}$ & $4.48^{* *}$ & $397.76^{* *}$ & $4.52^{* *}$ \\
\hline $\mathrm{H} \mathrm{xV}$ & 12 & $1.46^{* *}$ & $1.51^{* *}$ & $5.40^{* *}$ & $0.68^{* *}$ \\
\hline YHV & 12 & $0.51^{* *}$ & $0.45^{* *}$ & 12.61 & $0.19^{* *}$ \\
\hline Error & 64 & 0.24 & 0.18 & 11.20 & 0.22 \\
\hline
\end{tabular}

Table 2: Combined analysis of variance for the studied characters.

*,** significant at 0.05 and 0.01 , respectively.

Harvesting age effects on cane and sugar yield traits

Results presented in Table (3) cleared that harvest ages significantly differed in brix, sucrose and purity percentages in the plant cane and $1^{\text {st }}$ ratoon crops, as well as across crops. Harvest date of 13 months recorded the highest mean values of these traits, except sucrose in $1^{\text {st }}$ ratoon crop as well as purity in $1^{\text {st }}$ ratoon crop and across crops where it recorded the highest values at age of 12 months, whereas 10 months recorded the lowest ones. These results are in agreement with those obtained by Muchow et al. (1998), Ahmed (2003), Abd El-Razek and Besheit (2011) and Hagos et al. (2014)[26,5,6,14] who reported that harvest age showed highly significant influence on brix, sucrose, and purity percentage.

\begin{tabular}{|c|c|c|c|c|c|c|c|c|c|}
\hline \multirow{2}{*}{ Harvest age } & \multicolumn{3}{|c|}{ Brix\% } & \multicolumn{3}{|c|}{ Sucrose\% } & \multicolumn{3}{|c|}{ Purity\% } \\
\hline & Pc & FR & Across crops & Pc & FR & Across crops & Pc & FR & Across crops \\
\hline 10-month & 16.36 & 17.38 & 16.87 & 13.22 & 14.37 & 13.8 & 80.49 & 82.59 & 81.54 \\
\hline 11-month & 17.98 & 18.68 & 18.33 & 15.13 & 15.88 & 15.5 & 84.08 & 84.95 & 84.51 \\
\hline 12-month & 19.45 & 20.07 & 19.76 & 16.93 & 17.38 & 17.16 & 87.04 & 86.54 & 86.79 \\
\hline 13-month & 20.98 & 20.3 & 20.64 & 18.26 & 17.34 & 17.8 & 87.07 & 85.41 & 86.24 \\
\hline \multicolumn{10}{|c|}{ LSD 0.05} \\
\hline Harvest age $(\mathrm{H})$ & 0.46 & 0.24 & 0.23 & 0.43 & 0.2 & 0.21 & 0.57 & 0.74 & 0.41 \\
\hline H x Year & \multicolumn{3}{|c|}{0.33} & \multicolumn{3}{|c|}{0.29} & \multicolumn{3}{|c|}{0.59} \\
\hline
\end{tabular}

Table 3: Harvest age effects on studied traits in plant cane, first ratoon and across Crops.

Data given in Table (4) showed that harvest date along crushing season (from10 to 13 months old) had a significant effect on reducing sugars, fiber and richness percentage (Pol\%) in the plant cane, $1^{\text {st }}$ ratoon crop, as well as the across crops. Harvest date 13 months harvest recorded the highest values of fiber percentages.

\begin{tabular}{|c|c|c|c|c|c|c|c|c|c|}
\hline \multirow{2}{*}{ Harvest age } & \multicolumn{3}{|c|}{ Reducing sugar \% } & \multicolumn{3}{c|}{ Fiber \% } & \multicolumn{3}{c|}{ Richness \% } \\
\cline { 2 - 11 } & Pc & FR & Across crops & Pc & FR & Across crops & Pc & FR & Across crops \\
\hline 10- month & 1.14 & 0.93 & 1.04 & 10.74 & 11.51 & 11.13 & 11.28 & 12.17 & 11.73 \\
\hline 11- month & 0.92 & 0.47 & 0.69 & 11.39 & 11.72 & 11.56 & 12.82 & 13.41 & 13.12 \\
\hline 12- month & 0.51 & 0.34 & 0.42 & 11.89 & 11.98 & 11.93 & 14.26 & 14.63 & 14.45 \\
\hline 13- month & 0.34 & 0.38 & 0.36 & 12.46 & 12.36 & 12.41 & 15.28 & 14.54 & 14.91 \\
\hline \multicolumn{8}{|c|}{ LSD at 0.05} \\
\hline Harvest age (H) & 0.18 & 0.08 & 0.09 & 0.63 & 0.1 & 0.29 & 0.38 & 0.17 & 0.19 \\
\hline H x Year & \multicolumn{9}{|c|}{0.12} \\
\hline
\end{tabular}

Table 4: Effect of harvest age on reducing sugars, fiber and richness percentages in plant cane, first ratoon and across crops. 


\section{Open Access Journal of Agricultural Research}

The plant cane, $1^{\text {st }}$ ratoon and across crops. Whereas 12 months recorded the highest ones in reducing sugars except first ratoon and in Richness\% except across crops, otherwise, 13 months harvest recorded the highest values. Jadhav et al. (2000) [27] noted significant differences among harvesting ages in reducing sugars percentage. Hagos et al. (2014) [14] noticed that increasing harvest age significantly influenced pol\% parameters. Ahmed et al. (2016) [7] they noted that reducing sugars and richness percentages in juice was significantly affected by harvesting ages.
Results illustrated in Table (5) revealed that delaying harvest date from 10 up to 13 months age significantly increased sugar recovery percentage, cane and sugar yield/fad in both plant cane, $1^{\text {st }}$ ratoon and across crops. But harvest age at 13 months did not significantly increase cane and sugar yield compared with harvesting at 12 months, in other words these were no significant differences between harvesting at 12 and 13 months, whereas 10 months recorded the lowest ones.

\begin{tabular}{|c|c|c|c|c|c|c|c|c|c|}
\hline \multirow{2}{*}{ Harvest age } & \multicolumn{3}{|c|}{ Sugar recovery \% } & \multicolumn{3}{c|}{ Cane yield (ton/fad) } & \multicolumn{3}{c|}{ Sugar yield (ton/fad) } \\
\cline { 2 - 10 } & Pc & FR & Across crops & Pc & FR & Across crops & Pc & FR & Across crops \\
\hline 10- month & 8.73 & 9.61 & 9.17 & 49.28 & 53.17 & 51.22 & 4.31 & 5.07 & 4.69 \\
\hline 11- month & 10.22 & 10.77 & 10.49 & 54.93 & 55.82 & 55.38 & 5.62 & 6.01 & 5.82 \\
\hline 12- month & 11.63 & 11.9 & 11.76 & 56.96 & 57.69 & 57.33 & 6.64 & 6.88 & 6.76 \\
\hline 13- month & 12.54 & 11.79 & 12.17 & 57.71 & 59.02 & 58.36 & 7.25 & 6.97 & 7.11 \\
\hline \multicolumn{8}{|c|}{ LSD 0.05} \\
\hline Harvest age (H) & 0.31 & 0.16 & 0.15 & 2.41 & 1.85 & 1.35 & 0.45 & 0.22 & 0.36 \\
\hline H x Y & \multicolumn{8}{|c|}{ NS } \\
\hline
\end{tabular}

Table 5: Effect of harvest time on studied traits in plant cane, first ratoon and across Crops.

These results might be attributed to increase of growth and hence an expected increase in cane yield, as well as the increase in sugar yield may be due to increase in sucrose, sugar recovery percentages which reflected on sugar yield as a final product. These results are in line with those obtained by Jadhav et al. Ahmed and Abd ElRazek and Besheit $[27,5,6]$ who reported that delaying harvesting from 10 to 13 month increased sugar recovery percentage, cane and sugar yield.

\section{Variety Effects on Cane and Sugar Yield Traits}

Data given in Table (6) revealed that brix, sucrose, and purity percentages were significantly affected by the

\begin{tabular}{|c|c|c|c|c|c|c|c|c|c|}
\hline \multirow{2}{*}{ Varieties } & \multicolumn{3}{|c|}{ Brix\% } & \multicolumn{3}{|c|}{ Sucrose\% } & \multicolumn{3}{|c|}{ Purity\% } \\
\hline & Pc & FR & Across crops & Pc & FR & Across crops & Pc & FR & Across crops \\
\hline C 57-14 & 18.05 & 17.88 & 17.96 & 15.63 & 14.89 & 15.26 & 86.53 & 83.25 & 84.89 \\
\hline C 203-8 & 18.61 & 20.09 & 19.35 & 15.24 & 17.07 & 16.15 & 81.45 & 84.93 & 83.19 \\
\hline GT 54-9 & 17.79 & 18.49 & 18.14 & 14.91 & 15.76 & 15.34 & 83.28 & 84.92 & 84.1 \\
\hline G 2003-47 & 20.4 & 19.96 & 20.18 & 17.92 & 17.34 & 17.63 & 87.76 & 86.9 & 87.33 \\
\hline G 99-160 & 18.6 & 19.12 & 18.86 & 15.74 & 16.15 & 15.94 & 84.34 & 84.35 & 84.34 \\
\hline \multicolumn{10}{|c|}{ LSD 0.05} \\
\hline Varieties (V) & 0.24 & 0.67 & 0.35 & 0.29 & 0.61 & 0.33 & 0.83 & 0.68 & 0.53 \\
\hline Vx Years & \multicolumn{3}{|c|}{0.49} & \multicolumn{3}{|c|}{0.47} & \multicolumn{3}{|c|}{0.75} \\
\hline
\end{tabular}

examined sugar cane varieties in the $1^{\text {st }}, 2^{\text {nd }}$ seasons and across crops. Sugar cane variety G2003-47 recorded the highest brix sucrose and purity percentages in all crops, except brix percentage in $1^{\text {stratoon }}$ crop. Differences among varieties could be due to differences in their growth and response to the surrounding environmental conditions. These results are in agreement with those reported by Besheit et al. [28] and Ahmed [5], who found significant differences among varieties for brix, sucrose and purity degrees. 


\section{Open Access Journal of Agricultural Research}

Table 6: Mean performance of five varieties for brix $\%$, sucrose $\%$ and purity $\%$ in plant cane (PC), first ratoon (FR) and across crops.

Data in Table (7) indicated that the mean values of reducing sugars, fiber and richness percentages were significantly varied among the studied sugar cane varieties in the plant cane, 1 stratoon and across crops. The variety of G.2003-47 surpassed the other four varieties and produced the highest values of these traits. The

\begin{tabular}{|c|c|c|c|c|c|c|c|c|c|}
\hline \multirow{2}{*}{ Varieties } & \multicolumn{3}{|c|}{ Reducing sugar\% } & \multicolumn{3}{c|}{ Fiber\% } & \multicolumn{3}{c|}{ Richness\% } \\
\cline { 2 - 11 } & Pc & FR & Across crops & Pc & FR & Across crops & Pc & FR & Across crops \\
\hline C 57-14 & 0.51 & 0.54 & 0.53 & 11.95 & 11.53 & 11.74 & 13.16 & 12.61 & 12.89 \\
\hline C 203-8 & 1.06 & 0.34 & 0.7 & 11.3 & 11.9 & 11.6 & 12.92 & 14.38 & 13.65 \\
\hline GT 54-9 & 0.87 & 0.76 & 0.82 & 11.08 & 11.94 & 11.51 & 12.67 & 13.27 & 12.97 \\
\hline G 2003-47 & 0.25 & 0.32 & 0.29 & 12.23 & 12.03 & 12.13 & 15.04 & 14.6 & 14.82 \\
\hline G 99-160 & 0.94 & 0.68 & 0.81 & 11.55 & 12.08 & 11.81 & 13.31 & 13.58 & 13.45 \\
\hline \multicolumn{8}{|c|}{ LSD 0.05} \\
\hline Varieties (V) & 0.14 & 0.11 & 0.1 & 0.44 & 0.12 & 0.22 & 0.28 & 0.51 & 0.28 \\
\hline V x Years & \multicolumn{9}{|c|}{0.12} \\
\hline
\end{tabular}

Table 7: Mean performance of five varieties for reducing sugar\%, fiber\% and richness $\%$ in plant cane (PC), first ratoon (FR) and across crops.

Results presented in Table (8) indicated that the mean values of sugar recovery, cane and sugar yield were significantly varied among the studied cane varieties in the plant cane, $1^{\text {st }}$ ratoon and across crops. The G2003-47

variation of these traits between the studied varieties may be due to varietal characteristic. Similar findings were obtained by Hagos et al (2014) [14] who reported that significant difference of quality parameters was observed among four sugarcane varieties.

\begin{tabular}{|c|c|c|c|c|c|c|c|c|c|}
\hline \multirow{2}{*}{ Varieties } & \multicolumn{3}{|c|}{ Sugar recovery\% } & \multicolumn{3}{c|}{ Cane yield (ton/fad) } & \multicolumn{3}{c|}{ Sugar yield (ton/fad) } \\
\cline { 2 - 11 } & Pc & FR & Across crops & Pc & FR & Across crops & Pc & FR & Across crops \\
\hline C 57-14 & 10.7 & 10 & 10.35 & 52.33 & 49.94 & 51.14 & 5.62 & 5.01 & 5.32 \\
\hline C 203-8 & 10.14 & 11.57 & 10.86 & 52.2 & 42.11 & 47.15 & 5.32 & 4.89 & 5.1 \\
\hline GT 54-9 & 10.05 & 10.71 & 10.38 & 56.73 & 65.15 & 60.94 & 5.76 & 7.02 & 6.39 \\
\hline G 2003-47 & 12.35 & 11.9 & 12.13 & 57.5 & 60.48 & 58.99 & 7.14 & 7.21 & 7.17 \\
\hline G 99-160 & 10.66 & 10.92 & 10.79 & 54.83 & 64.44 & 59.64 & 5.93 & 7.05 & 6.49 \\
\hline \multicolumn{9}{|c|}{ LSD 0.05} \\
\hline Varieties (V) & 0.24 & 0.43 & 0.24 & 3.67 & 1.42 & 1.93 & 0.45 & 0.33 & 0.27 \\
\hline V x Year & \multicolumn{7}{|c|}{0.34} \\
\hline
\end{tabular}

Table 8: Mean performance of five varieties for sugar recovery\%, cane and sugar yield in plant cane (PC), first ratoon (FR) and across crops.

The increase in sugar yield for G2003-47 variety may be due to superiority in sucrose \%, sugar recovery \% and cane yield which reflected consequently on sugar yields. These differences could be attributed to the genetic structure of the evaluated sugarcane varieties. Differences among cane varieties in these traits were also found by

Kabiraj et al. Hossain et al. Rahman et al. Islam et al. Hagos

variety surpassed the other four varieties and produced the highest values of these traits.

et al. and Mehareb et al. [14,29-33], who carried out studies on different sugarcane varieties/promising clones and found different trend for sugar recovery, cane and sugar yield.

The Relationship bBetween Harvesting Age and Studied Varieties

Eid M Mehareb and Abazied SR. Genetic Variability of Some Promising Sugarcane Varieties (Saccharum Spp) Under Harvesting Ages for Juice Copyright@ Eid M Mehareb and Abazied SR. Quality Traits, Cane and Sugar Yield. J Agri Res 2017, 2(2): 000127. 


\section{Open Access Journal of Agricultural Research}

The interaction between harvesting age and the studied varieties is summarized in Figures from 1 to 8 for brix $\%$, sucrose $\%$, purity $\%$, reducing sugar $\%$, fiber $\%$, richness $\%$, recovery sugar $\%$, cane yield and sugar yield. Brix percentage presented in (Figure 1) showed that harvesting age had a significant effect on brix $\%$ of sugarcane juice.

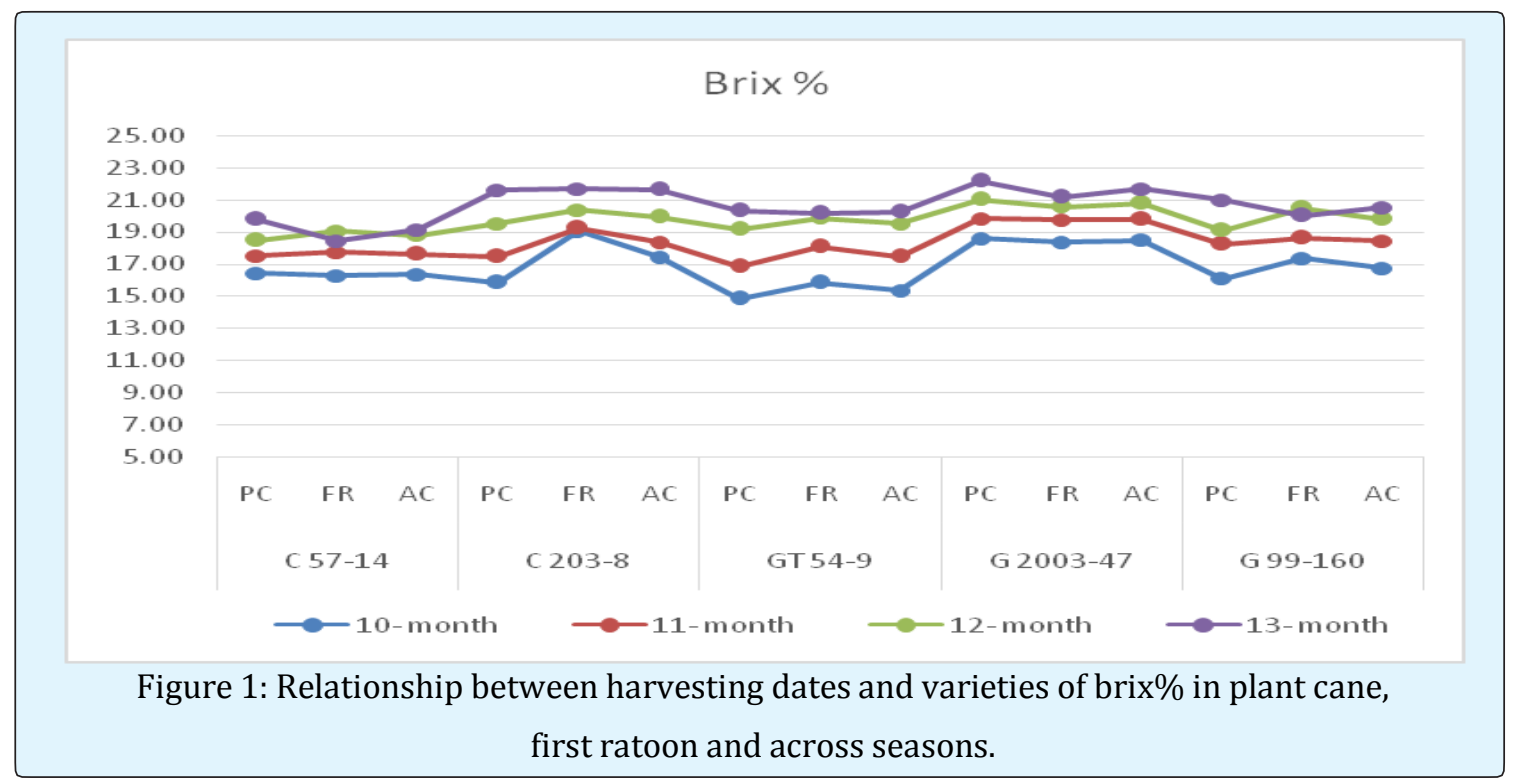

Delaying harvesting age caused a significant increase. These increases in brix values of sugar cane juice at the 13-month may be due to the continuous accumulation of solids as harvest age progress towards the end (from 10 to 13 month old). The highest value of brix in plant cane season and across crops recorded by interaction of variety of G2003-47 when it harvested at 13-month (22.18\% and $21.68 \%$, respectively) but the highest value of brix \% in first ratoon recorded C 203-8 in the last harvesting age $(21.69 \%)$. Sucrose\%, presented in (Figure 2) cleared significant differences among the harvesting ages.

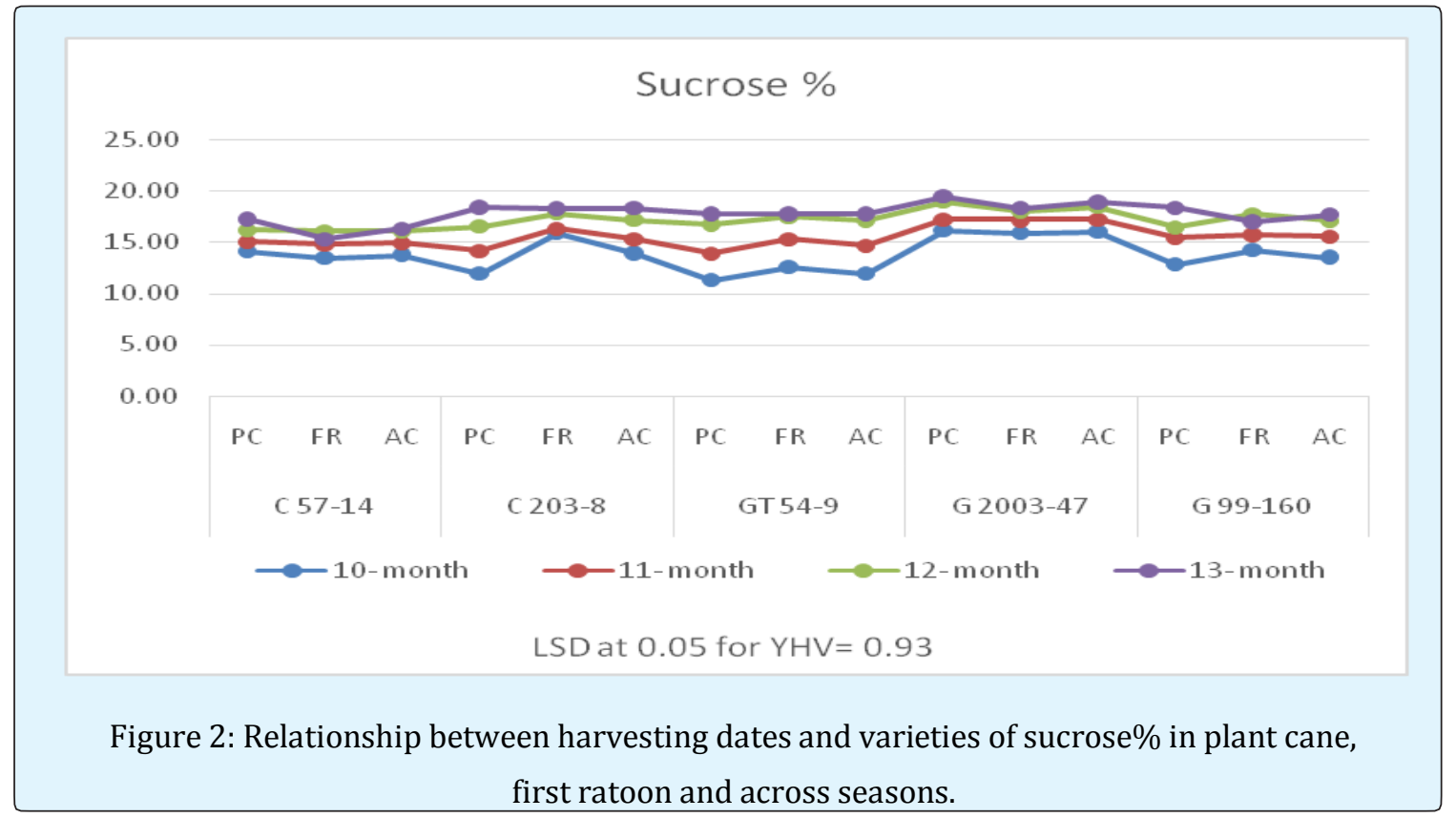

The highest sucrose\% value was in age of 13 months for G2003-47 in plant cane, first ratoon and across crops
(19.45\%, 18.36\% and 18.9\%, respectively). The increase in sucrose\% for G.2003-47 at 13 months old may be due 
to the enzymes or change of the reducing sugars and nonsucrose materials to sucrose.

Similar results were obtained by who reported that maximum brix and sucrose percentages accumulation occurs at a later crops age. Purity\% presented in (Figure 3) was significantly affected by cane varieties and harvesting ages.

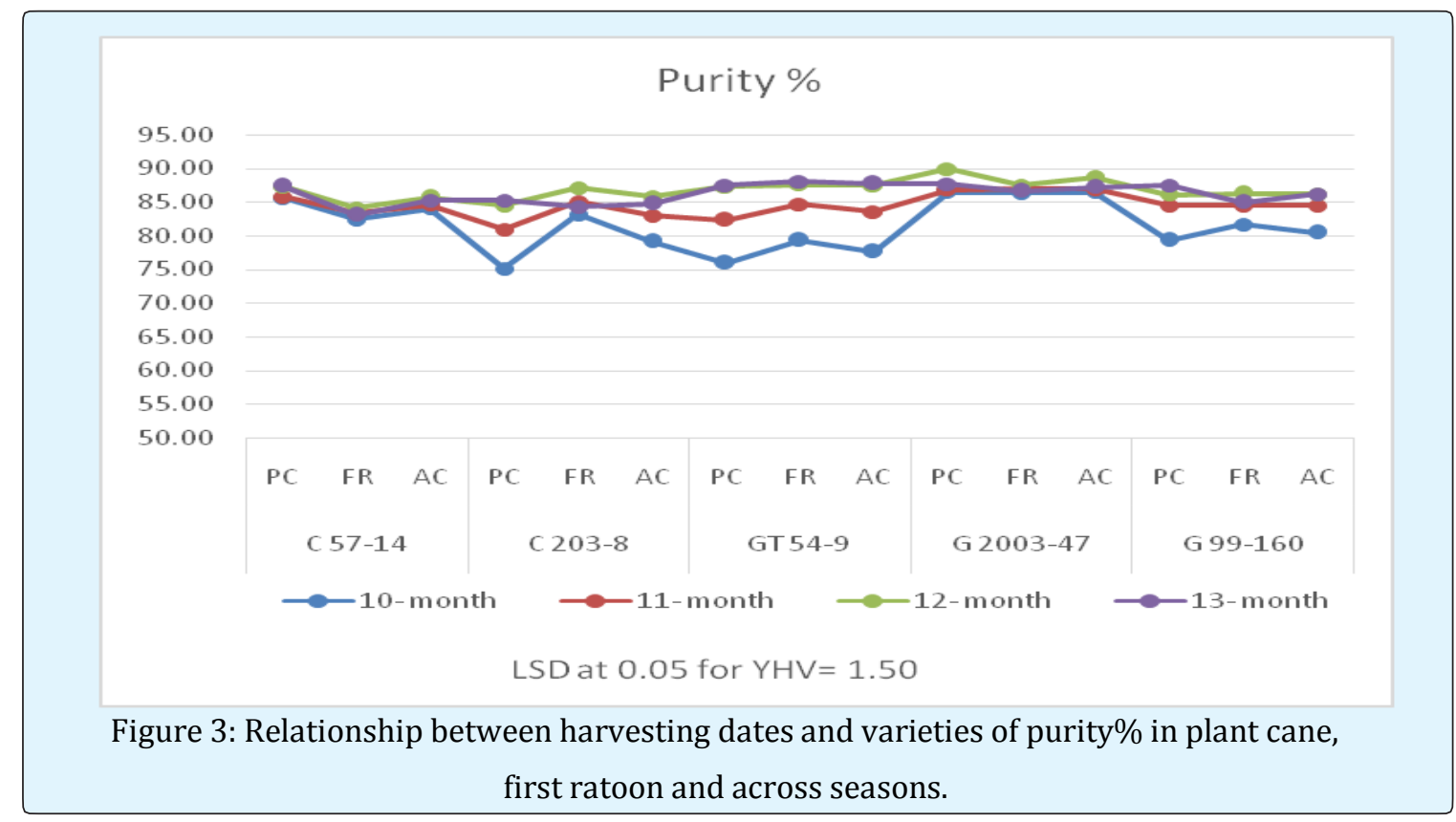

The highest value of purity $\%$ in plant cane and across crops was recorded by G2003-47 variety at age of 12 months compared with commercial variety G.T. 54-9 in plant cane and across crops $(89.97 \%$ and 88.76 , respectively) but in first ratoon crop, G.T.54-9 was the highest value in purity (88.03\%).

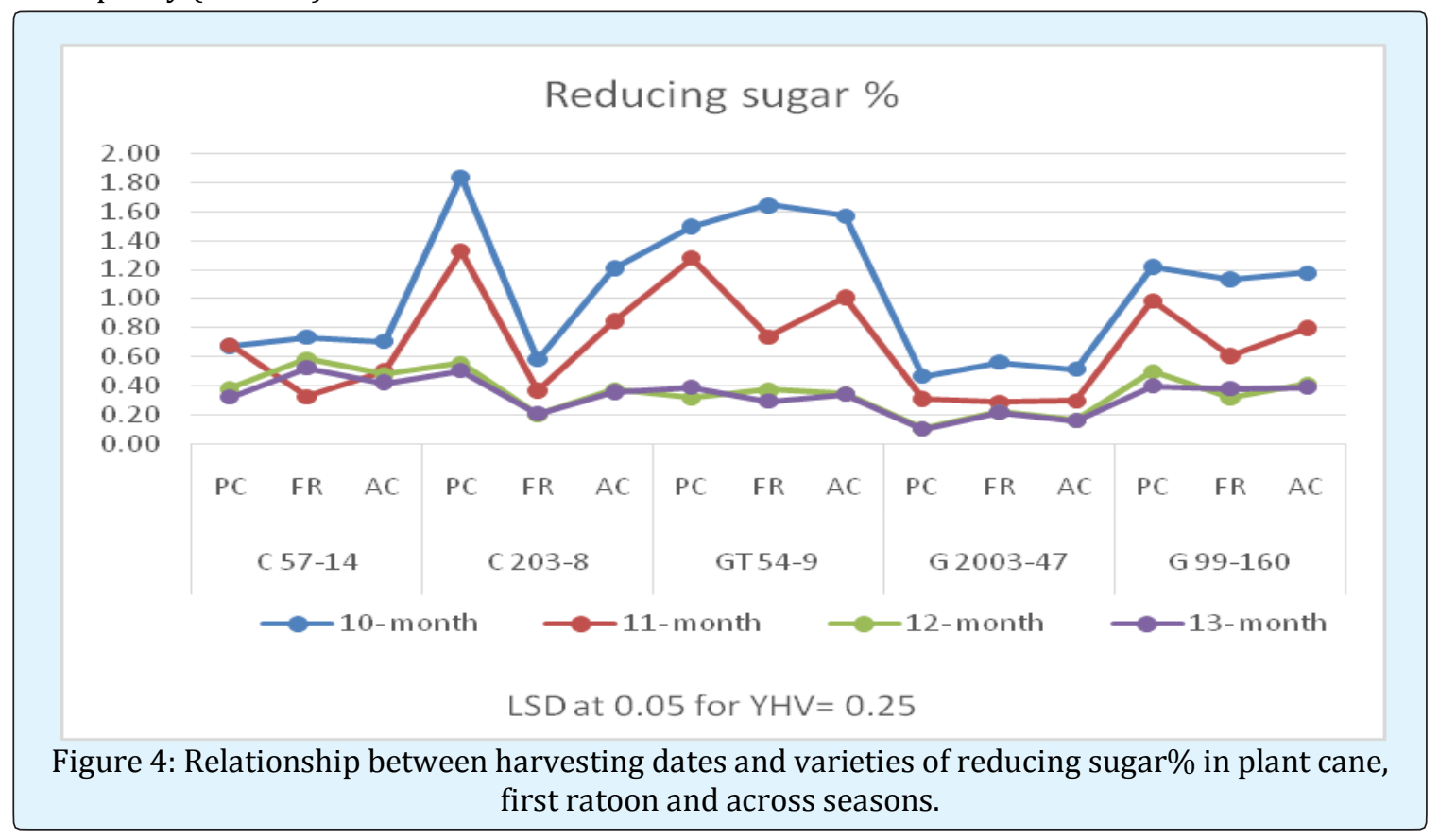
ages as well as the studied varieties. The highest value was recorded in the first harvesting date for all studied varieties (Figure 4). 
H1 x C 57-14 had the highest value in plant cane (1.84\%), but H1 x GT 54-9 was the highest in the first ratoon and across crops ( $1.64 \%$ and $1.57 \%$, respectively). This result is mainly due to differences in the genitcal constitution of the tested varieties. Similar results were obtained by Robertson et al. [34], who suggested high concentrations of reducing sugars in stalks harvested at a young age.

Fiber \% (Figure 5), recorded the lowest value at 10 months harvest by the promising sugarcane variety $\mathrm{C} 57$ 14 in the first ratoon and check variety GT 54-9 in plant cane and across crops.

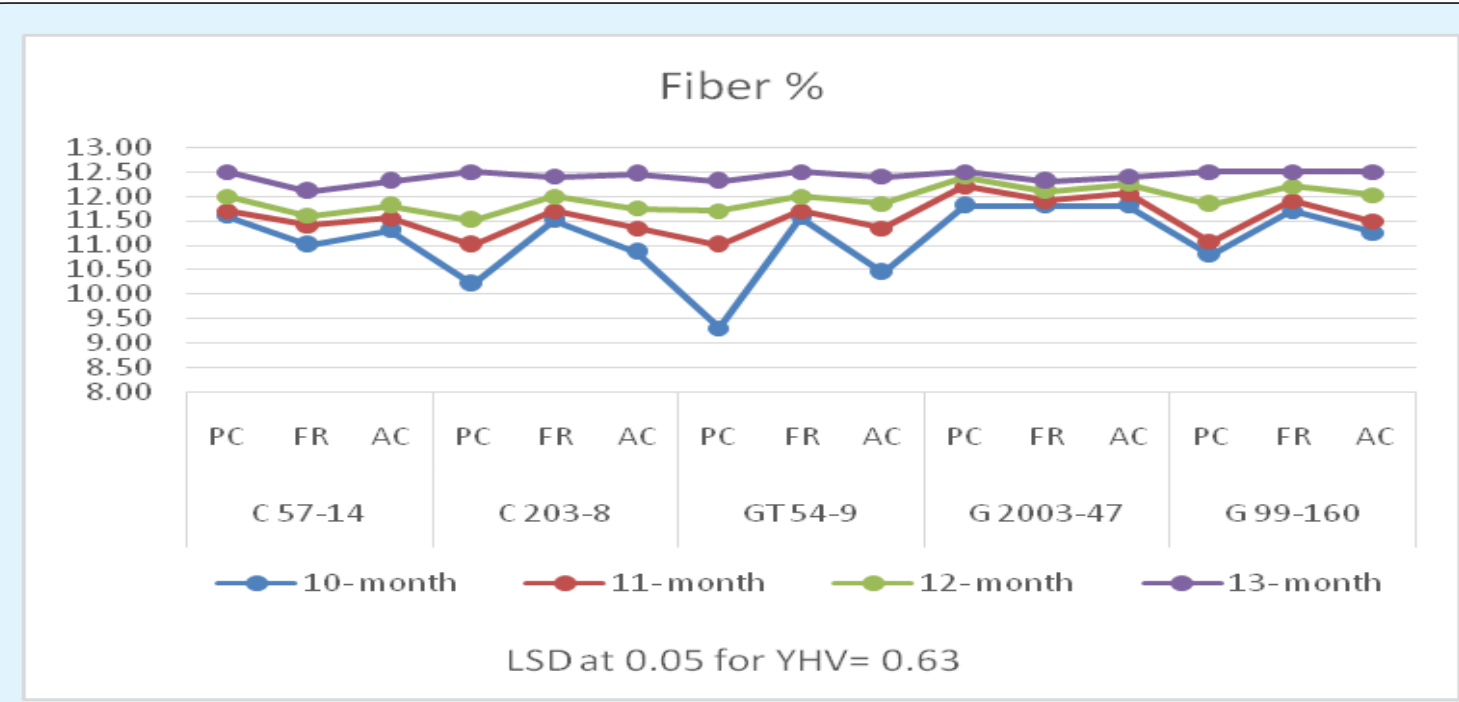

Figure 5: Relationship between harvesting age and varieties of fiber\% in plant cane, first ratoon and across seasons.

Fiber \% recorded the highest value at 13 months by all varieties, which recorded the same value $(12.5 \%)$. Delaying the harvest age from 10 to 13 -months old significantly increased the richness \%. This may be due to the variation in their sucrose and fiber content. Also results showed significant interaction of varieties with harvesting age (Figure 6), G2003-47 recorded the highest value of richness \% (pol\%) in the last harvesting date (13 months) for all seasons, plant cane, first ratoon and across crops (16.28\%, $15.38 \%$ and 15.83\%, respectively), G2003-47 showed significant increase of pol \% compared with commercial variety GT 54-9.

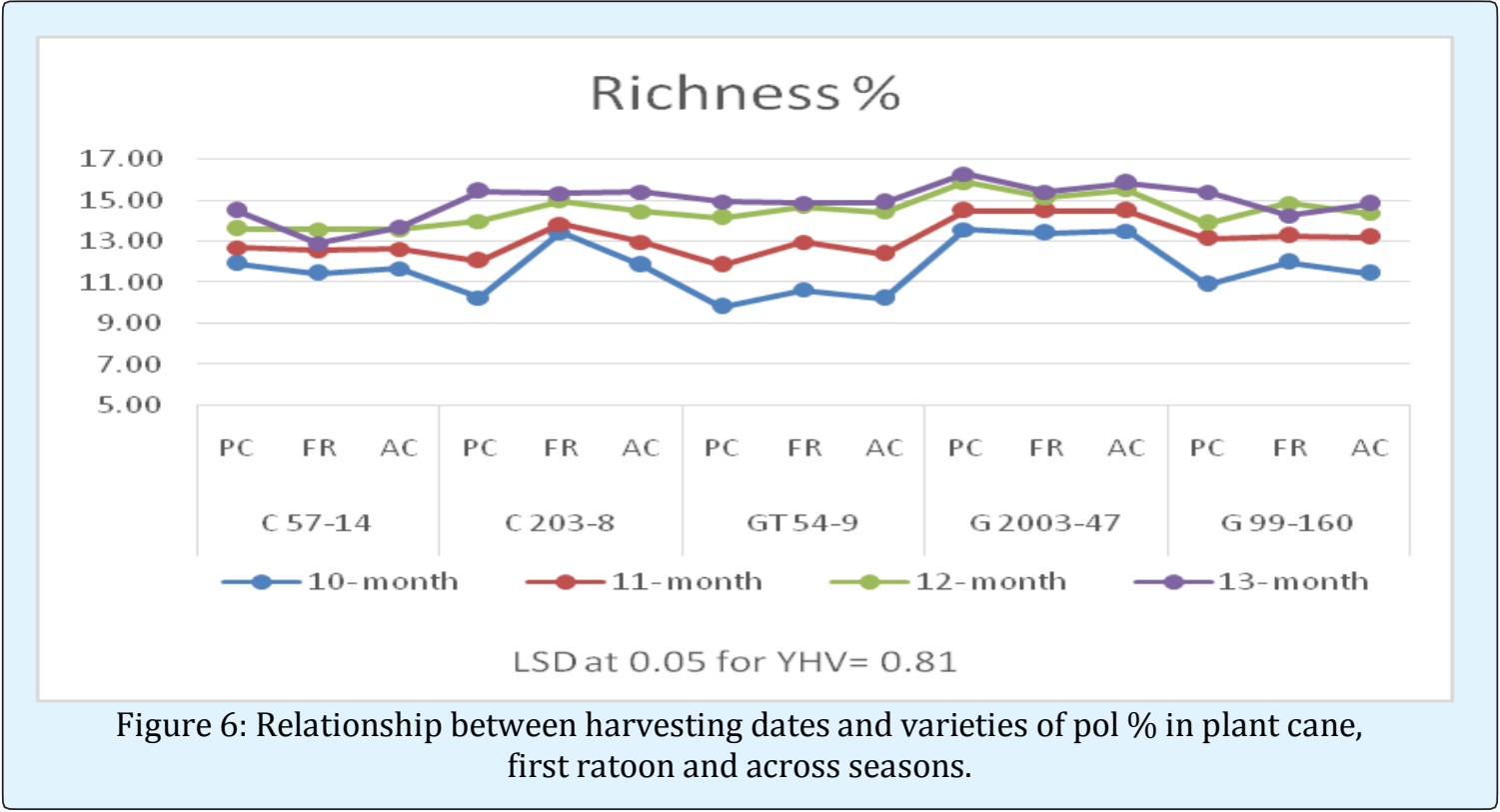

Sugar recovery \% presented in (Figure 7) showed that harvesting age had a significant effect on sugar recovery \%. 


\section{Open Access Journal of Agricultural Research}

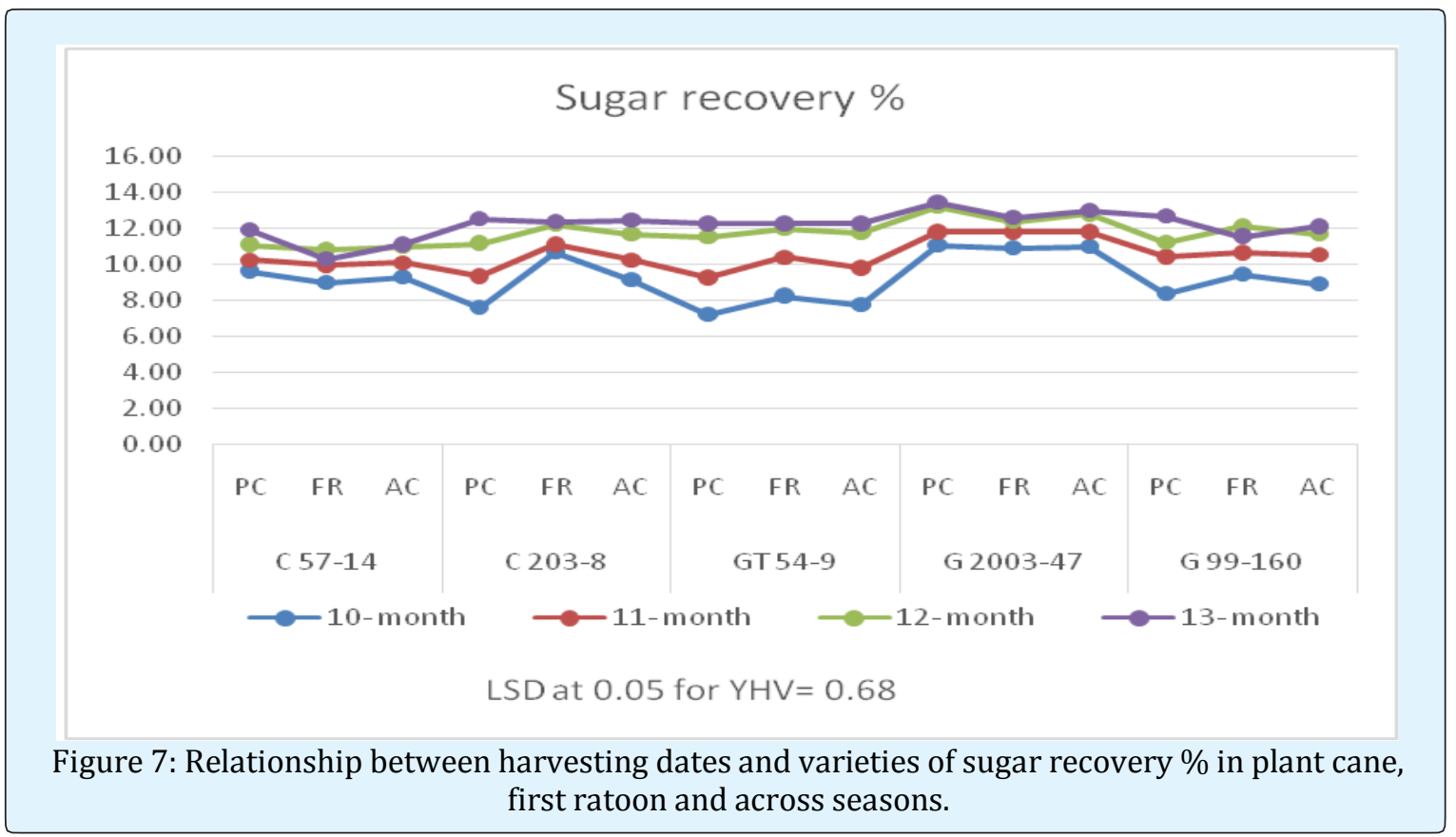

Delaying harvesting age caused a significant increase in sugar recovery \%; this increase may be due to the increase in sucrose \%. The highest value in all seasons was recorded by G2003-47 (13 months) for plant cane, first ratoon and across crops $(13.41 \%, 12.56 \%$ and
$12.98 \%$, respectively). Cane yield (Figure 8) for the last harvesting age recorded the highest value. This finding may be due to the increase in millable cane length, thickness and weight.

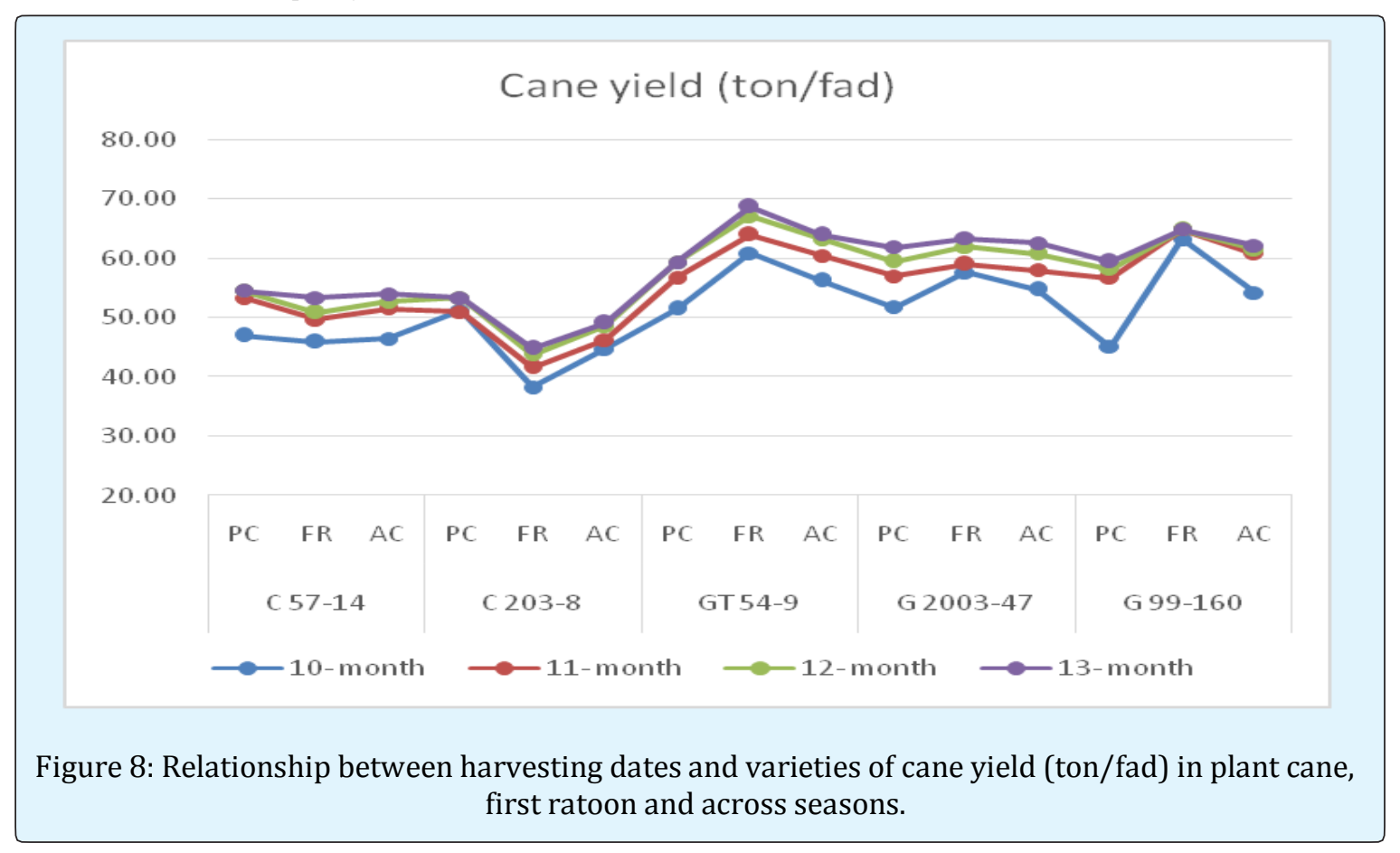

Variety G2003-47 showed the highest cane yield (61.87 ton/fad), but for the first ratoon and across crops, G.T. 549 showed the highest cane yield (68.65 and 63.99 ton/fad, respectively). Superiority of G2003-47 and, G.T. 54-9 may be due to their better millable cane traits. 
This result is in harmony with Mehareb et al., Islam et al., Rahman et al., Hossain et al. and Kabiraj et al. [29-33], who carried out studies on different sugarcane varieties/promising clones and found different trend for cane yield per unit area.

(Figure 9) showed that sugar yield differed significantly between the studied varieties as well as harvesting ages. G.T. 54-9 recorded the highest sugar yield in first ratoon ( 8.40 ton/fad) at 13 months, however, G.2003-47 showed the highest value for plant cane and across crops. At the same harvesting time, it recorded (8.29 ton/fad) for plant cane and (8-12 ton/fad) for across crops. This superiority in sugar yield may be due to its better cane yield traits.

\section{Sugar yield (ton/fad)}

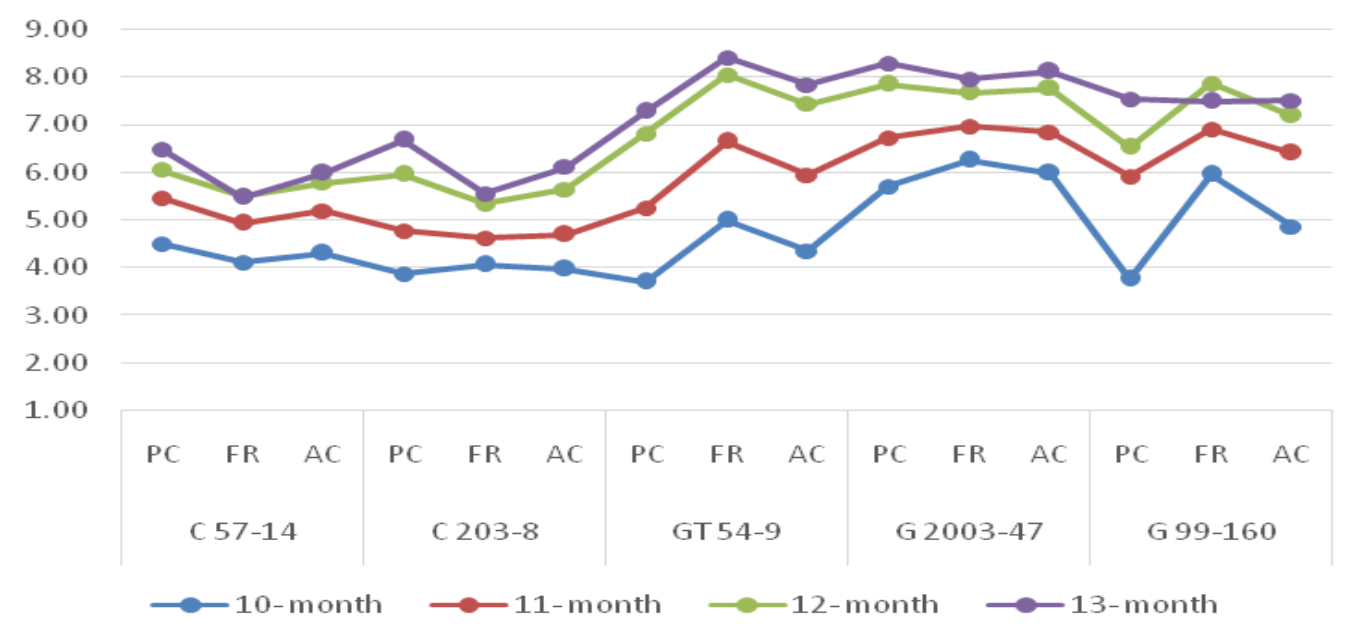

Figure 9: Relationship between harvesting dates and varieties of sugar yield (ton/fad) in plant cane, first ratoon and across seasons.

\section{Genetic Components}

Genetic variance is important as it describes the amount of genetic variation present for the trait. Data in (Tables $9 \& 10)$ revealed that high genetic variance $\left(\sigma^{2} \mathrm{~g}\right)$ relative to environmental variance for all traits under study across seasons. Examination of variance components, calculated from full model analysis across seasons showed the important contribution of $\sigma^{2}$ gy and $\sigma^{2}$ gyh in determining the phenotypic variance for all studied traits except reducing sugar (Tables $9 \& 10$ ).

\begin{tabular}{|c|c|c|c|c|}
\hline Genetic component & Richness & Sugar recovery & Cane yield & Sugar yield \\
\hline$\sigma^{2} \mathrm{e}$ & 0.081 & 0.058 & 3.735 & 0.074 \\
\hline$\sigma^{2} \mathrm{~g}$ & 2.335 & 2.054 & 10.986 & 1.373 \\
\hline$\sigma^{2} \mathrm{gy}$ & 0.279 & 0.271 & 0.312 & 0.1 \\
\hline$\sigma^{2} \mathrm{gh}$ & 0.159 & 0.176 & 0.001 & 0.082 \\
\hline$\sigma^{2} \mathrm{gyh}$ & 0.428 & 0.391 & 8.877 & 0.114 \\
\hline$\sigma^{2} \mathrm{ph}$ & 2.571 & 2.284 & 12.408 & 1.461 \\
\hline $\mathrm{H} \%$ & 90.827 & 89.904 & 88.543 & 93.968 \\
\hline $\mathrm{PCV} \%$ & 11.834 & 13.868 & 6.339 & 19.846 \\
\hline $\mathrm{GCV} \%$ & 11.278 & 13.149 & 5.965 & 19.238 \\
\hline
\end{tabular}

Table 9: Variance components, heritability (H\%), phenotypic coefficient of variation (PCV\%) and genotypic coefficient of variation (GCV\%) for brix , sucrose, purity, reducing sugar and fiber percentage across seasons. 


\section{Open Access Journal of Agricultural Research}

\begin{tabular}{|c|c|c|c|c|c|}
\hline Genetic component & Brix & Sucrose & Purity & Reducing sugar & Fiber \\
\hline$\sigma^{2} \mathrm{e}$ & 0.121 & 0.109 & 0.28 & 0.008 & 0.049 \\
\hline$\sigma^{2} \mathrm{~g}$ & 3.169 & 3.65 & 5.266 & 0.089 & 0.303 \\
\hline$\sigma^{2} \mathrm{gy}$ & 0.308 & 0.444 & 1.401 & 0.012 & 0.065 \\
\hline$\sigma^{2} \mathrm{gh}$ & 0.117 & 0.251 & 2.429 & 0.015 & 0.009 \\
\hline$\sigma^{2} \mathrm{gyh}$ & 0.415 & 0.627 & 2.945 & 0.146 & 0.235 \\
\hline$\sigma^{2} \mathrm{ph}$ & 3.409 & 4.018 & 6.953 & 0.117 & 0.369 \\
\hline $\mathrm{H} \%$ & 92.958 & 90.843 & 75.728 & 75.596 & 82.083 \\
\hline $\mathrm{PCV} \%$ & 9.774 & 12.481 & 3.111 & 54.31 & 5.164 \\
\hline GCV\% & 9.424 & 11.896 & 2.707 & 47.221 & 4.679 \\
\hline
\end{tabular}

Table 10: Variance components, heritability (H\%), phenotypic coefficient of variation (PCV\%) and genotypic coefficient of variation (GCV\%) for richness, sugar recovery, cane yield and sugar yield across seasons.

The estimates for phenotypic coefficient of variation (PCV) were higher than genotypic coefficient of variation (GCV) in all the traits, suggesting that the apparent variation is not only due to genetics but also due to environmental influences. However, the differences between PCV and GCV for most of the traits were small, indicating high prospects for genetic progress through selection under the conditions of this investigation. Low estimates of genotypic and phenotypic coefficients of variation (GCV and PCV) were coupled with high heritability recorded for fiber, pol percentage, and sugar yield while moderate estimates of GCV and PCV were coupled with high heritability for brix, sucrose, sugar recovery and cane yield. In this respect, Gupta and Chatterjee, Agrawal, Delvadia and Patel and Patel et al. (2006) [35-38] reported that high heritability was observed for sugar yield.

Also, Agrawal, Nagarajan et al. and Tawfic et al. $[36,39,40]$, reported that sucrose percentage showed high heritability. Moderate values of GCV and PCV were coupled with high heritability for brix, sucrose, sugar recovery and cane yield. The highest phenotypic coefficient of variation (PCV) and genotypic coefficient of variation was observed for reducing sugar $54.310 \%$ and 47.221\%). Traits exhibiting relatively high GCV estimates may respond favorably to selection. In this study medium heritability estimate has been recorded for purity $(75.728 \%)$ and reducing sugar $(75.596 \%)$, indicating that selection for these traits would not be as effective as for the other traits. These findings agree with Chaudhary [16], who reported similar values for purity percentage in some sugarcane genotypes. Knowledge of variability and heritability of characters is essential for identifying those amenable to genetic improvement through selection [41]. Results of the current study indicated that use of the traits with high heritability as selection criteria together with cane yield could lead to genetic improvement in cane yield. These results are in agreement with these reported by Sanghera et al. [42].

\section{References}

1. Di Bella LP, Stringer JK, Wood AW, Royleand AR, Holzberger GP (2008) What impact does time of harvest have on sugarcane crops in the Herbert River District?. Proc Aust Soc Sugar Cane Technol 30: 337348.

2. Chapman LS, Leverington KC (1976) Optimizing harvest schedules in the Mackay area. Proceedings of the Queensland Society of Sugar Cane Technologists 43: 33-38.

3. Leverington KC, Hogarth DM,Ham GJ (1978) The influence of time of harvest on yield in the Burdek in district. Proceedings of the Queensland Society of Sugar Cane Technologists 45: 27-30.

4. McDonald LM, Wood A, Muchow R (1999) A review of the effect of harvest time on sugarcane productivity. Proc Australian Society of Sugar Cane Tech 21: 177184.

5. Ahmed AZ (2003) Harvesting age with relation to yield and quality of some promising sugar cane varieties Egypt. J Appl Sci 18(7): 114-124.

6. Abd El-Razek AM, Besheit SY (2011) Effect of genotype, environment and time of harvest on sugarcane yields at middle and upper Egypt. J Southern Agric China 43(3): 294-301.

7. Ahmed AZ, El-Bakry Sakina A, Abazied R (2016) Assessment of the optimum age for harvesting some 


\section{Open Access Journal of Agricultural Research}

promising sugar cane varieties. Minia J of Agric Res \& Develop 36(4): 635-651.

8. Donaldson RA, Rdshaw KA, Rhodes R, Van Antwerpen R (2008) Season Effects on Productivity of some commercial South African Sugarcane Cultivars. I: Biomass and Radiation use efficiency. Proc S Afr Sug Technol Ass 81: 517-527.

9. Sundara B (2000) Sugarcane Cultivation. Vikas publishing house Pvt ltd, New Delhi.

10. Verma RS (2004) Sugarcane Projection Technology in India. Inter Book Distributing Co Lucknow India.

11. Das PK, Nayak N, Mahapatra SS (1997) Performance of early maturing sugarcane genotypes in the coastal plains of Orissa. Sugarcane and Its Problems. Indian Sugar 47(2): 111-113.

12. Domaingue R, Ramdoyal K, Mamet LD, Bissessur D, Rivet L (1998) Breeding and selection programme at the Mauritius Sugar Industry Research Institute, MSIRI. Country Presentations. $4^{\text {th }}$ ISSCT Breeding and Germplasm Workshop 18-22.

13. Di Bella LP, Rixon C, Armytage P, Davies B, Dorahy K, et al. (2007) The 2006 Herbert MODDUS® pilot program. Proc Aust Soc Sugar Cane Technol 29: 368376.

14. Hagos H, Mengistu L, Mequanint Y (2014) Determining optimum harvest age of sugarcane varieties on the newly establishing sugar project in the tropical areas of tendaho, Ethiopia. Adv Crop Sci Tech 2(5): 156-159.

15. Netsanet A, Dengia A, Getaneh A, Mengistu L (2015) Possibility of reducing harvesting time in sugarcane using bioactivators. Inter J Agric and Crop Sci 8(4): 525-528.

16. Chaudhary RR (2001) Genetic Variability and Heritability in sugarcane. Nepal Agric Res J 4 \& 5: 5659.

17. Tena E, Mekbib F, Ayana A (2016) Heritability and correlation among sugarcane (Saccharum spp.) yield and some agronomic and sugar quality traits in Ethiopia. American J Plant Sci 7: 1453-1477.

18. AOAC (1995) Official methods of analysis. Published by the A. O. A. C., Box 540, Washington, DC.

19. Singh RK, Singh GP (1998) Effect of sampling time on efficacy of selection for quality traits in sugarcane. Sugar Cane 3: 13-17.

20. Plskhow BP (1976) Analysis in Agriculture Biochemistry. $2^{\text {nd }}(E d n$.$) Moscow, Kales.$

21. Yadav RL, Sharma RK (1980) Effect of nitrogen level and harvesting date on quality characteristics and yield of four sugar cane genotypes. Indian J Agric Sci 50: 581-589.

22. Mathur RB (1981) Handbook of cane sugar technology. Oxford \& IBH Publishing Co.

23. Snedecor GW, Cochran WG (1981) Statistical Methods. Seventh Ed., Iowa State Univ. Press, Ames, Iowa, USA.

24. Steel RGD,Torrie JH (1980) Principles and Procedures of Statistics. Second Edition, McGraw-Hill Comp. New York.

25. Leclerg EL, Leonard WH, Clark AG (1962) Field plot technique. Minnesota, Burgess Publishing Co.

26. Muchow RC, Higgins AJ, Rudd AV, Ford AW (1998) Optimizing harvest date in sugar production: a case study for the Mossman mill region in Australia: II Sensitivity to crop age and crop class distribution. Field Crops Research 57(3): 243-251.

27. Jadhav HD, Mungara TS, Patil JP, Hasure RR, Jadhav BS, et al. (2000) Effect of harvesting age on juice and Jaggery quality and yield of different sugar cane varieties under pre-seasonal planting. Coop Sugar 32(2): 113-117.

28. Besheit SY, Abo-Dooh A, Maria GB, Ali MK, Abed Elkareem HA (1999) Evaluation and borer sensitivity of some new Egyptian parameters of sugar cane varieties. Egypt J Agric Res 76(1): 191-203.

29. Kabiraj RC, Rahman MM, Rahman MA, Alam KS (2007) Performance of some sugarcane varieties in Northern Region of Bangladesh. Bangladesh J Sugarcane 29: 110-114.

30. Hossain SMI, SUK Eusufzai, MA Rahman (2008) Effect of different irrigation levels on growth and yield of sugarcane. Bangladesh J Sugarcane 30: 51-61.

31. Rahman MS, Islam MS, Amanullah ASM, Islam MA, Ohiduzzaman M (2010) Potentiality of seven sugarcane varieties in High Ganges River Flood Plain Soils of Bangladesh. Inter J Sustain Agric Tech 6(2): 


\section{Open Access Journal of Agricultural Research}

04-07.

32. Islam MS, Miah MAS, Begum MK, Alam MR, Arefin MS (2011) Growth, yield and juice quality of some selected sugarcane clones under water-logging stress condition. World J Agric Sci 7(4): 504-509.

33. Mehareb EM, Abou-Elwafa SF, Galal MOA (2015) Comparative Performance of sugarcane genotypes for ratoon ability in early clonal selection stages. Journal of Sugarcane Research 5(2): 11- 21.

34. Robertson MJ, Muchow RC, Wood AW, Campbell JA (1996) Accumulation of reducing sugars by sugarcane: effects of crop age, nitrogen supply and cultivar. Field Crops Res 49(1): 39-50.

35. Gupta RK, Chatterjee A (2002) Study on some genetic parameters and its implication in selection of sugarcane (Saccharum officinarum). Cooperative Sugar 33(10): 823-826.

36. Agrawal KB (2003) Estimates of variation and heritability of some quantitative characters in sugarcane. Ann Agric Res 24(2): 379-382.

37. Delvadia DR, Patel AD (2006) Genetic variability and heritability in sugarcane. Madras Agric J 93(7-12): 165-168.
38. Patel KC, Mali SC, Patel DU, Vashi RD (2006) Variability, correlation and path analysis in sugarcane (Saccharum spp.). Crop Res (Hisar) 32(2): 213-218.

39. Nagarajan R, Alarmelu S, Shanthi RM (2006) Variability for yield and quality attributes in interspecific progenies of Saccharum spp. Proc $2^{\text {nd }}$ National Plant Breed Congres, Coimbatore, India, 145152.

40. Tawfic YH, Al-Labbody AS, El-Sheikh SRE (2008) Estimation of genetic variance and broad sense heritability of sugarcane (Saccharum spp). Alex Sci Exch J 29(2): 77-84.

41. Vidya KL, Oommen SK, Vijayaraghava K (2002) Genetic variability and heritability of yield and related characters in yard-long bean. J Trop Agric 40: 11-13.

42. Sanghera GS, Tyagi V, Kumar R, Thind KS, Sharma B (2015) Genetic variability, association and their dissection through path analysis for cane yield and its component traits in early maturing sugarcane clones J Sci 5(1): 28-34. 